\title{
Ultimate Flexural Capacity of Reinforced Concrete Elements Damaged by Corrosion
}

\author{
Antonio Bossio $^{1}\left(\mathbb{D}\right.$, Stefania Imperatore ${ }^{2, *}$ (i) and Mahdi Kioumarsi ${ }^{3}$ (i) \\ 1 Department of Structures for Engineering and Architecture, University of Naples Federico II, \\ Via Claudio, 21, 80125 Napoli, Italy \\ 2 Department of Civil Engineering, "Niccolò Cusano" University of Rome, Via Don Carlo Gnocchi, 3, \\ 00166 Rome, Italy \\ 3 Department of Civil Engineering and Energy Technology, Oslo Metropolitan University, Pilestredet 35, \\ 0166 Oslo, Norway \\ * Correspondence: stefania.imperatore@unicusano.it
}

Received: 14 June 2019; Accepted: 29 June 2019; Published: 2 July 2019

check for updates

\begin{abstract}
Worldwide, steel corrosion is one of the greatest deterioration problems for reinforced concrete structures. Comparing some experimental results from literature with a complex FEM model, the present paper points out the principal aspects that characterize the static behavior of reinforced concrete (RC) elements damaged by corrosion. Moreover, the nondimensional abaci defined for some specific case studies finalized to the evaluation of the residual flexural strength of corroded elements highlight the dangerousness of the corrosion degradation if the failure of the element is governed by the steel.
\end{abstract}

Keywords: corrosion; FEM model; degradation abaci; flexural strength

\section{Introduction}

The increased aggressiveness and environmental pollution have highlighted the issue of deterioration in reinforced concrete (RC), previously considered unalterable and nondegradable material with a long life. In recent decades, corrosion degradation has occurred on reinforced concrete structures, causing loss of load-bearing capacity, both in the service and in the ultimate limit state. The first evidence of corrosion degradation is formation of rust stains on the surface of the artifact; then, the concrete cracks [1] and the steel-concrete interaction is lost, the corrosion rate increases, and the reinforcement section is reduced. If not properly countered, depending on environmental aggressiveness, ductility and flexural strength can be drastically reduced, and consequently, the service life drops [2].

The evaluation of the behavior of structural elements subjected to corrosive phenomena cannot disregard the study of the degradation process and its implications on both the materials and the sectional geometry (Figure 1). To estimate the static behavior of RC elements damaged by corrosion, the first aspect to consider is related to the steel reinforcement degradation. Previous studies have demonstrated that the reduction of the steel cross-section is accompanied by a decay in the material and mechanical properties in tension and compression, under monotonic and cyclic behavior [3-11]. Since steel consumption is accompanied by the formation of corrosion products (characterized by a density lower than the original material), cracking and cover spalling of the concrete also occur [12-17]. Consequently, the bond interaction between concrete and steel is significantly modified [18-25]. 


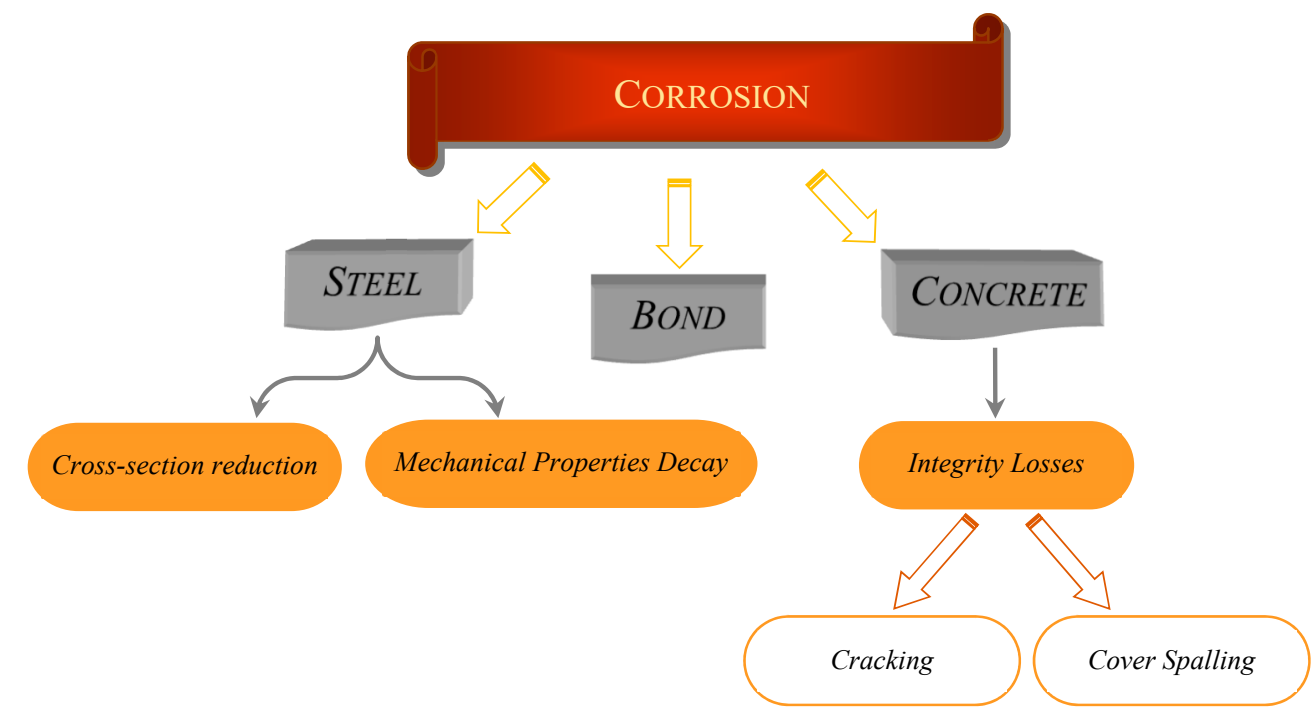

\section{STRUCTURAL CAPACITY REDUCTION}

DUCTILITY LOSS

VARIATION IN THE FAILURE MODE

Figure 1. Corrosion influences on the behavior of a structural element.

Among the main contributions of analyzing the flexural behavior of corroded RC beams, the experimental works of Rodriquez et al. [26-30] must firstly be mentioned. These experimental results showed that the collapse is caused by steel failure accompanied by significant concrete cracking for a low amount of reinforcement, while a high reinforcement amount that is due to concrete crushing and buckling is accompanied by a considerable ductility reduction. Capozucca [31] observed $45 \%$ ultimate strength reduction for 13\% diameter reduction, while Mangat and Elgarf [32] stated 25\% ultimate strength reduction for $9.5 \%$ corrosion level. Analyzing the global behavior of naturally corroded beams, Castel [33] highlighted a significant increase of the maximum displacement and stiffness and ductility reduction. Moreover, Torres-Acosta [34] showed that $20 \%$ corrosion level causes about $60 \%$ flexural strength decay; Azad [35] confirmed the increase of deformation as a consequence of the corrosion; Zhang [36] related the pitting corrosion development with the ultimate capacity and the bending stiffness reduction, that is, the more sensitive parameter due to the steel-concrete bond loss. According to the latter, $\mathrm{Du}$ [37] experimentally found that under the same loads, the time-dependent deflections of corroded RC beams increased more rapidly than those of uncorroded RC beam and reached their limiting deflections prematurely. Other studies [38-40] on the flexural strength degradation of RC beams subjected to various levels of chloride-induced reinforcing corrosion, reported that the failure mode can change from ductile to brittle when corrosion occurs.

The brief review of the works proposed in the scientific literature shows that a reliable procedure to estimate the residual life of a reinforced concrete structure subjected to corrosion is not yet well defined. This procedure, due to a widespread uncertainty on the experimental results, often influenced by uncontrolled corrosion distribution. For this reason, at the scientific and regulatory level, a reliable methodology for simulating the flexural behavior of corrosion-damaged reinforced concrete elements has not yet been proposed. Only taking into account the degradation of the mechanical properties of reinforcements, the sectional capacity of any RC element appears significantly reduced in the time [40-48]. This aspect may significantly affect the seismic behavior of corroded structures [49-54]. Obviously, the decay may become more significant if the bond and cracking are also considered. 
The aim of the present paper was to define a simple procedure to evaluate the residual flexural capacity of a corroded reinforced concrete beam by means of nondimensional abaci. To this purpose, the degradation model proposed by one the authors [11] was applied. Moreover, to evaluate their reliability, the approach was applied to a numerical model, in which a beam characterized by a uniform corrosion and tested by Rodriguez [30] was simulated. In the case of pitting corrosion, in fact, the reliability of the approach has been already demonstrated in other, previous studies $[47,55]$.

The proposed abaci clearly show the decay in the flexural strength with the corrosion level as a function of the sectional reinforcement amount.

\section{The Corroded Element with Flexure: Numerical Modeling}

In order to predict the mechanical behavior of a corroded RC beam, an experimental case was selected to be simulated and analyzed using the nonlinear finite element (NLFE) method. In the chosen $\mathrm{RC}$ beam, the amount of the uniform corrosion on the tensile reinforcement was $14 \%$ steel cross-section reduction. In addition, geometry dimensions and rebar detailing of the selected beam are shown in Figure 2. Based on the amount of corrosion, the cross-section and material properties of corroded reinforcement (Equations (1)-(3)) with decayed bond-slip behavior (Equation (4)) were applied to the FE model.

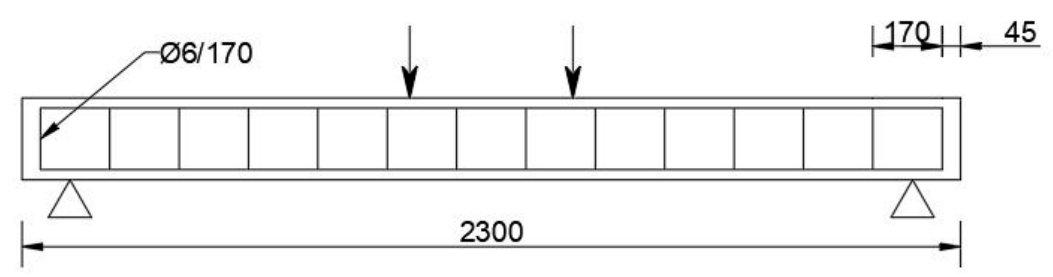

(a)

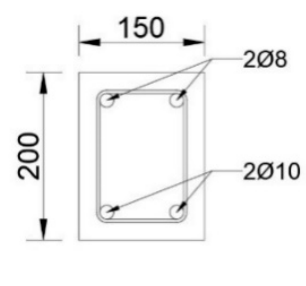

(b)

Figure 2. Geometry of simulated corroded reinforced concrete (RC) beams investigated by Rodriguez et al. [30] in mm. (a) longitudinal section; (b) cross-section.

\subsection{Selected Experimental Case Study}

Rodriguez [30] investigated the effect of reinforcement corrosion on the residual capacity of corroded and uncorroded RC beams under a four-point bending test. In these experimental tests, many beams with various types of failure were investigated. In order to assess the applicability of the decay laws proposed by one the authors [11], a beam for a numerical simulation was chosen from [30]. Specifically, the mechanical properties of the reinforcement were modified according to Equations (1)-(3) for the yielding strength, the ultimate strength, and the ultimate strain, respectively:

$$
\begin{gathered}
\frac{\sigma_{y, \text { corr }}}{\sigma_{y, \text { uncorr }}}=1-0.143453 \cdot M_{\text {corr }}[\%] \\
\frac{\sigma_{u, \text { corr }}}{\sigma_{u, \text { uncorr }}}=1-0.125301 \cdot M_{\text {corr }}[\%] \\
\frac{\varepsilon_{u, \text { corr }}}{\varepsilon_{u, \text { uncorr }}}=e^{-0.024983 \cdot M_{\text {corr }}[\%]}
\end{gathered}
$$

where $\sigma_{y}$ and $\sigma_{u}$ are, respectively, the yielding and ultimate stress of the reinforcement, $M_{c o r r}$ is the percentage of mass loss due to the corrosion, and $\varepsilon_{u}$ is the ultimate strain. It is assumed that the yielding strain can be directly derived by the $\sigma_{y}$, since the elastic modulus of the reinforcement does not significantly change after the corrosion degradation. 
Geometry dimensions and rebar detailing of the selected simply supported beam are shown in Figure 2. In the chosen beam, the amount of the uniform corrosion on the tensile reinforcement was $14 \%$ steel cross-section reduction, and the uniaxial compressive strength of concrete is $34 \mathrm{MPa}$. In the present study, reduction of the mechanical properties of corroded reinforcement was considered using Equations (1)-(3).

\subsection{FE Analysis and Material Properties}

The two-dimensional (2D) NLFE analysis was performed in DIANA [56] by incorporating the material models. Only half of the beams were modeled to take advantage of the symmetry in geometry, supports, and loading conditions. It was assumed that the corrosion is uniformly distributed along the tensile reinforcements. A vertical stepwise incremental displacement was applied at the loading point in the model (see Figure 3). In addition, the nonlinear problems were solved using the modified Newton-Raphson approach.

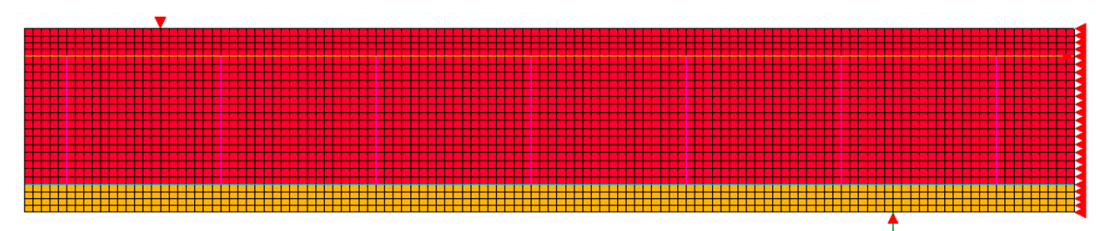

Figure 3. Mesh size and finite element model of one half of the beam.

The concrete was modeled using four-node quadrilateral plane stress elements. The tensile and compressive behaviors of concrete were represented through a smeared rotating crack model with Hordijk and elastic-ideally plastic models, respectively. The details of these models are described in [56]. It was reported that the compressive strength of concrete in compression zone, which is subject to cracks due to the corrosion, might be reduced in comparison with that of undamaged concrete [57-60]. In this study, the reduced value of compressive strength was assigned to the concrete elements of the top cover for 2D FEM using a proposed equation by Coronelli and Gambarova [42].

\subsection{Bond-Slip Model}

In the FE model, a one-dimensional interface layer was modeled along the tensile rebars to consider the effect of bond-slip behavior. Interaction between the reinforcement and the concrete was modeled with $2+2$ node line interface elements in 2D models. For the simulated corroded beam, bond slip behavior based on the fib Model Code 2010 [61], which is confined with steel stirrups, was adopted. In this study, the bond slip behavior was modified based on the amount of the uniform corrosion and kept constant along the tensile rebar. In addition, the bond strength was calculated according to [43] as a function of the concrete strength, the cover-to-diameter ratio, and stirrup confinement:

$$
U_{\max }^{D}=R \cdot\left[0.55+0.24\left(c / d_{0}\right)\right] \cdot \sqrt{f_{c}}+0.191\left(\frac{A_{s w} \cdot \sigma_{y t}}{s_{s} \cdot d_{0}}\right)
$$

where $U_{\max }^{D}$ is the reduced bond strength, $c$ is the thickness of concrete cover, $d_{0}$ is the diameter of the anchored rebar, $f_{c}$ is the concrete compressive strength, $A_{s w}$ and $\sigma_{y t}$ are the stirrups cross-section and the stirrup yield strength, respectively, ss is the stirrup spacing, and $R$ is a coefficient that depends on the corrosion and is equal to 1 for the selected case study.

\subsection{Comparison between the Numerical and the Experimental Results}

The obtained load-displacement curve at mid-span of corroded beam from nonlinear FE analysis (Figure 4) indicates good agreement with experimental observation at the ultimate limit state (ULS) and serviceability limit state (SLS). The results of FE simulation prove the accuracy and 
applicability of the proposed decay laws (Equations (1)-(4)) to modify the mechanical properties of corroded reinforcements.

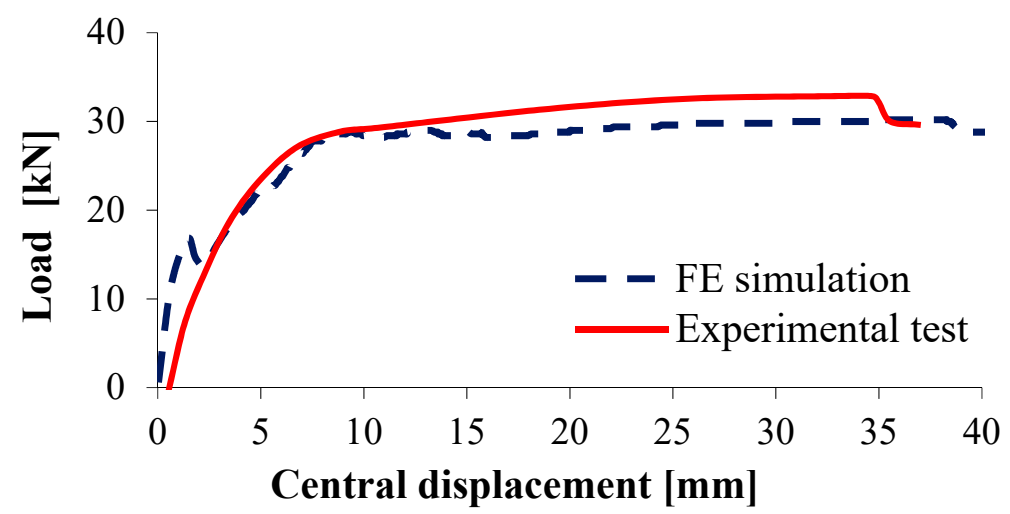

Figure 4. Comparison of load displacement curves at mid-span for 2D FE analysis and experimental results of a corroded RC beam no. 115; experimental data from [30].

\subsubsection{Nondimensional Abaci for the Residual Flexural Strength of Corroded Rectangular Sections}

The results proposed in the previous section highlight the feasibility of the decay laws in the estimation of the behavior of a corroded RC element under bending moment. As is well known, the flexural strength of a RC elements is characterized by the mechanical properties of the constituent materials, while its deformation is related to the interaction between the steel and the concrete and then by the sectional curvature. The latter, of course, influences both strains and tensional levels of the constituent materials. It also has relapses on the strength of section itself. In reinforced concrete elements, the perfect bond condition is usually assumed, and consequently, the full compatibility between concrete and reinforcement strains is then considered. When this hypothesis of decay for a high load level as well as when the cracking occurs, with the decrease of bond, the steel stress increases, reaching its maximum values on the crack. The tension stiffening effects results in a slight enhancement of the effective flexural strength of the element, then their neglection can then be regarded as conservative in terms of strength.

The application of decay laws for the steel to the classical models of structural engineering allows the definition of abaci to estimate the residual flexural strength of corroded RC element. The proposed relationships in the present paper were developed for the most typical pattern of exposed reinforced concrete beams in ordinary structures: the formed beam and the flat beam. For each kind of beam, the geometrical percentage of the tension reinforcement is varied in the range of $1.3 \% \mathrm{~A}_{c}$ and $4 \% \mathrm{~A}_{c}$, as proposed by EuroCode 2 [62]. For the compression reinforcement, a minimum quantity of $2 \phi 14$ diameter was imposed and increased up to the tensile reinforcement amount.

According to the Section 9.2 of EuroCode 2 [62], the minimum tension steel content should be:

$$
A_{s, \min }=0.26 \cdot \frac{f_{c t m}}{\sigma_{y}} \cdot b \cdot d
$$

where $f_{c t m}$ represents the mean tensile concrete strength, $\sigma_{y}$ the reinforcement yielding strength, and $b$ and $d$ represent the section width and effective height, respectively, remembering that the mechanical reinforcement percentage is defined as:

$$
\omega=\rho \cdot \frac{\sigma_{y}}{f_{c k}}
$$


$\rho$ being the geometrical reinforcement percentage and $f_{c k}$ the concrete compressive strength, a minimum mechanical reinforcement percentage, $\omega_{s, \min }$, may be defined as:

$$
\omega_{s, \min }=0.08 \cdot \frac{1}{\sqrt[3]{f_{c k}}}
$$

Then, assuming a (cubic) compressive strength of $35 \mathrm{MPa}$ for the concrete and reinforcements with a yielding strength of $450 \mathrm{MPa}$, the previous positions (Equations (5)-(7)) indicate a minimum tension reinforcement of $2 \phi 14$ for both a $(30 \times 60) \mathrm{cm}^{2}$ formed beam section and a $(70 \times 25) \mathrm{cm}^{2}$ flat beam section.

Parametric analyses have been performed considering three different corrosion scenarios: (i) a section corroded all around its perimeter; corrosion of steel in tension; the steel in compression corroded with half of the bars in tension in terms of mass loss. For each degradation condition, the pitting corrosion pattern was considered by applying the aforementioned decay laws and a classic uniaxial stress-plastic strain curve constitutive law to the reinforcements. According to EuroCode2 [62], the ultimate strength of steel is assumed equal to $540 \mathrm{MPa}$, while the characteristic strains are assumed equal to $0.655 \%$ o for hardening initiation and equal to $10 \%$ for collapse. The concrete is conventionally modeled to the conventional relationship of Mander [63], assuming the presence of stirrups $\phi 8 / 30$ accounts for the confinement.

The parametric analysis results were generalized by introducing the nondimensional ultimate bending moment after corrosion $\left(m_{u, c o r r}\right)$, defined as the ratio between the ultimate bending moment of the corroded section and the ultimate bending moment of the sound section. The adopted reinforcements for the both formed and flat beams are reported in Tables 1 and 2, respectively. Since $\omega_{c o r r}$ depends only on the tension reinforcement, the mechanical reinforcement percentage reduces linearly with the corrosion level (Figure 5).

Table 1. Compression and tension reinforcement in the formed beam.

\begin{tabular}{cccc}
\hline Tension Reinforcements & \multicolumn{3}{c}{ Compression Reinforcements } \\
\hline $2 \phi 14$ & $2 \phi 14$ & & \\
$3 \phi 16$ & $3 \phi 16$ & & \\
$3 \phi 20$ & $3 \phi 16$ & $3 \phi 20$ & \\
$3 \phi 24$ & $2 \phi 14$ & $3 \phi 16$ & $3 \phi 20$ \\
\hline
\end{tabular}

Table 2. Compression and tension reinforcement in the flat beam.

\begin{tabular}{cccc}
\hline Tension Reinforcements & Compression Reinforcements \\
\hline $6 \phi 14$ & $4 \phi 14$ & \\
$6 \phi 16$ & $4 \phi 16$ & & \\
$6 \phi 20$ & $4 \phi 20$ & & \\
$6 \phi 24$ & $4 \phi 24$ & & \\
$8 \phi 24$ & $4 \phi 24$ & $6 \phi 24$ & $8 \phi 24$ \\
\hline
\end{tabular}

For the considered sections, the nondimensional ultimate bending moment after corrosion $\left(m_{u, c o r r}\right)$ was plotted as a function of the mass loss of the reinforcement in tension. Both in the case of the flat and the formed beams, the uniform corrosion causes a linear decay of flexural capacity with increasing of the corrosion level, see Figures 6 and 7. The reduction is accompanied by a depth reduction of the neutral axis with the consequent increasing in curvature. Then, the work rate of the reinforcements in tension increases as its deformability. 


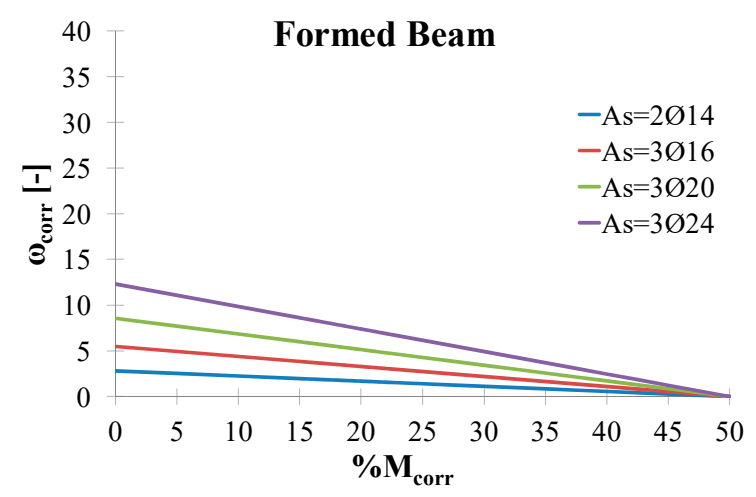

(a)

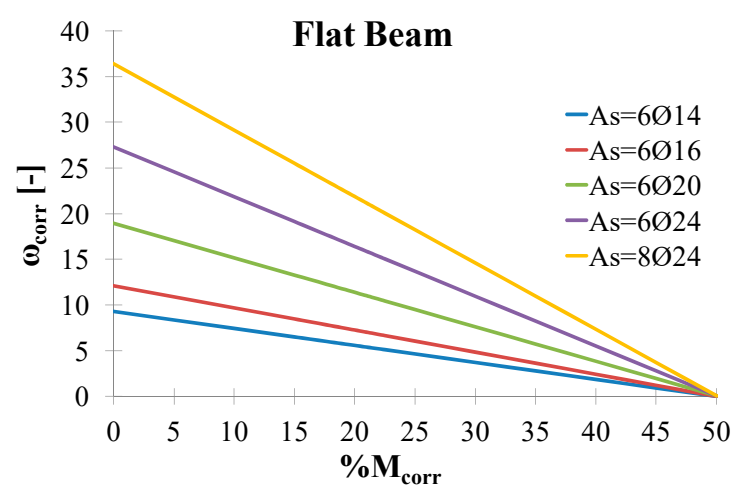

(b)

Figure 5. Decay of the mechanical reinforcement percentage with the corrosion levels. (a) formed beam; (b) flat beam.
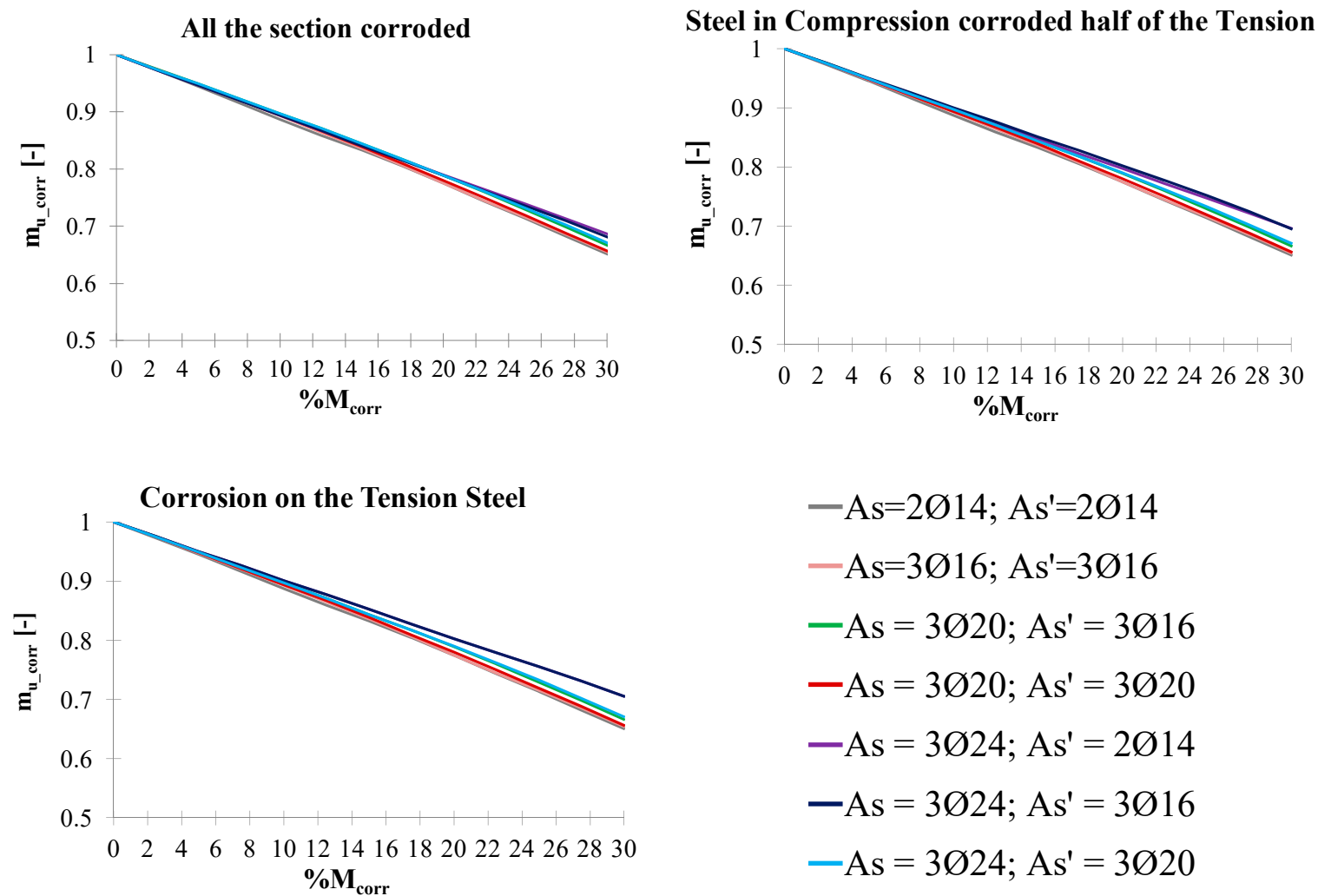

$$
\begin{aligned}
& -\mathrm{As}=2 \varnothing 14 ; \mathrm{As}^{\prime}=2 \varnothing 14 \\
& -\mathrm{As}=3 \varnothing 16 ; \mathrm{As}^{\prime}=3 \varnothing 16 \\
& -\mathrm{As}=3 \varnothing 20 ; \mathrm{As}^{\prime}=3 \varnothing 16 \\
& -\mathrm{As}=3 \varnothing 20 ; \mathrm{As}^{\prime}=3 \varnothing 20 \\
& -\mathrm{As}=3 \varnothing 24 ; \mathrm{As}^{\prime}=2 \varnothing 14 \\
& -\mathrm{As}=3 \varnothing 24 ; \mathrm{As}^{\prime}=3 \varnothing 16 \\
& -\mathrm{As}=3 \varnothing 24 ; \mathrm{As}^{\prime}=3 \varnothing 20
\end{aligned}
$$

Figure 6. Nondimensional ultimate bending moment for different corrosion scenarios—formed Beam, uniform corrosion.

Similar results were obtained for the all considered scenarios and reinforcement amount and configurations in the case of pitting corrosion, see Figures 8 and 9. This means that the behavior of a RC concrete member can be easily studied by applying decay laws to the mechanical properties of reinforcements [11] and assuming the same corrosion level on the different steel layers. However, it is important to point out the dangerousness of the pitting corrosion morphology, which induces a quasi-parabolic decrease of the flexural capacity of the element. 

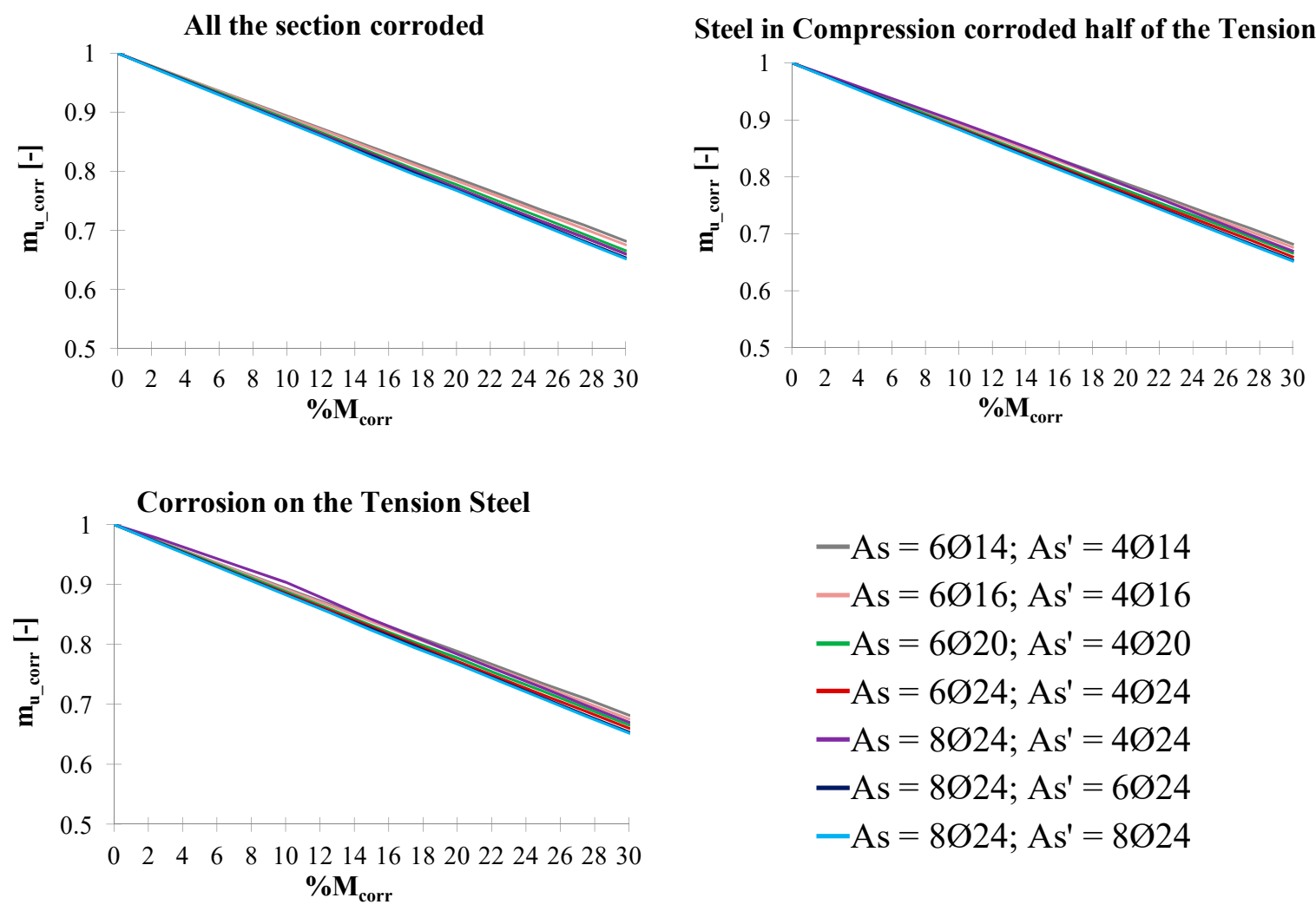

$$
\begin{aligned}
& -\mathrm{As}=6 \varnothing 14 ; \mathrm{As}^{\prime}=4 \varnothing 14 \\
& -\mathrm{As}=6 \varnothing 16 ; \mathrm{As}^{\prime}=4 \varnothing 16 \\
& -\mathrm{As}=6 \varnothing 20 ; \mathrm{As}^{\prime}=4 \varnothing 20 \\
& \text {-As }=6 \varnothing 24 ; \mathrm{As}^{\prime}=4 \varnothing 24 \\
& -\mathrm{As}=8 \varnothing 24 ; \mathrm{As}^{\prime}=4 \varnothing 24 \\
& -\mathrm{As}=8 \varnothing 24 ; \mathrm{As}^{\prime}=6 \varnothing 24 \\
& -\mathrm{As}=8 \varnothing 24 ; \mathrm{As}^{\prime}=8 \varnothing 24
\end{aligned}
$$

Figure 7. Nondimensional ultimate bending moment for different corrosion scenarios-flat Beam, uniform corrosion.
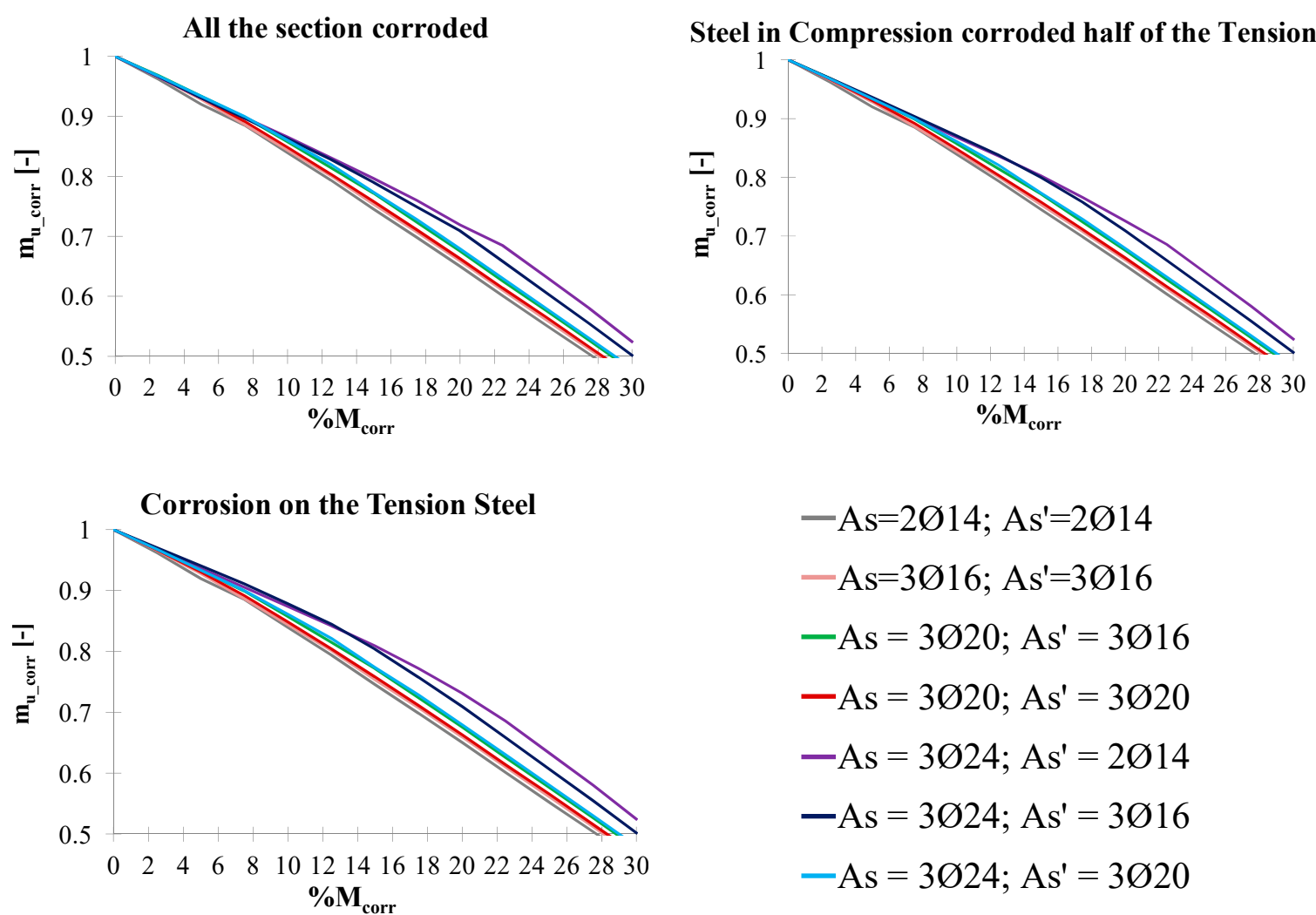

$$
\begin{aligned}
& -\mathrm{As}=2 \varnothing 14 ; \mathrm{As}^{\prime}=2 \varnothing 14 \\
& -\mathrm{As}=3 \varnothing 16 ; \mathrm{As}^{\prime}=3 \varnothing 16 \\
& -\mathrm{As}=3 \emptyset 20 ; \mathrm{As}^{\prime}=3 \varnothing 16 \\
& -\mathrm{As}=3 \emptyset 20 ; \mathrm{As}^{\prime}=3 \emptyset 20 \\
& -\mathrm{As}=3 \emptyset 24 ; \mathrm{As}^{\prime}=2 \emptyset 14 \\
& -\mathrm{As}=3 \varnothing 24 ; \mathrm{As}^{\prime}=3 \varnothing 16 \\
& -\mathrm{As}=3 \varnothing 24 ; \mathrm{As}^{\prime}=3 \varnothing 20
\end{aligned}
$$

Figure 8. Nondimensional ultimate bending moment for different corrosion scenarios-formed Beam, pitting corrosion. 

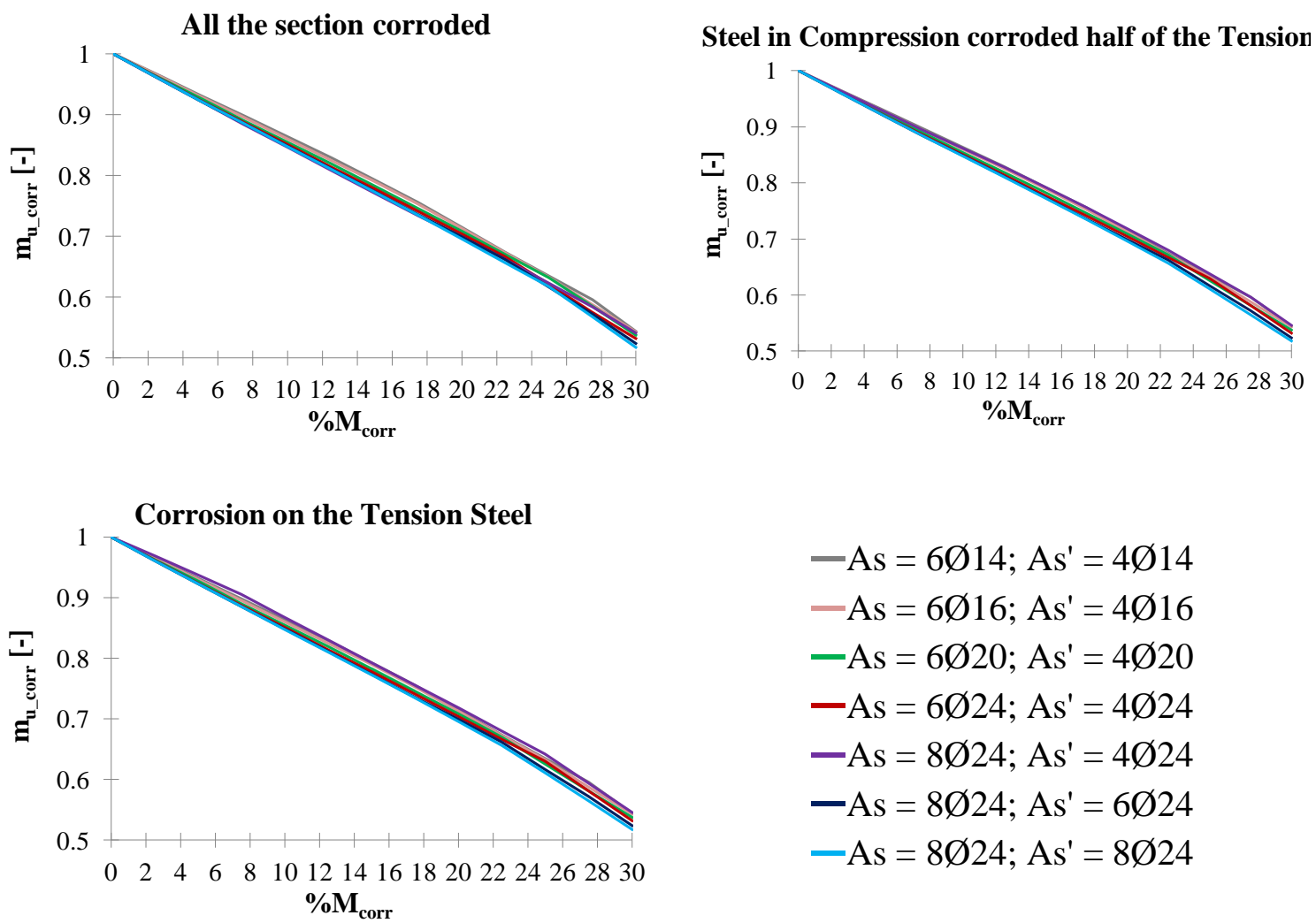

$$
\begin{aligned}
& -\mathrm{As}=6 \varnothing 14 ; \mathrm{As}^{\prime}=4 \varnothing 14 \\
& -\mathrm{As}=6 \varnothing 16 ; \mathrm{As}^{\prime}=4 \varnothing 16 \\
& -\mathrm{As}=6 \varnothing 20 ; \mathrm{As}^{\prime}=4 \varnothing 20 \\
& -\mathrm{As}=6 \varnothing 24 ; \mathrm{As}^{\prime}=4 \varnothing 24 \\
& -\mathrm{As}=8 \emptyset 24 ; \mathrm{As}^{\prime}=4 \varnothing 24 \\
& -\mathrm{As}=8 \emptyset 24 ; \mathrm{As}^{\prime}=6 \emptyset 24 \\
& -\mathrm{As}=8 \emptyset 24 ; \mathrm{As}^{\prime}=8 \emptyset 24
\end{aligned}
$$

Figure 9. Nondimensional ultimate bending moment for different corrosion scenarios—flat beam, pitting corrosion.

The analysis of the ultimate curvature of the two beam typologies appears very thought-provoking (Figure 10). In the case of the formed beams, both the corrosion level and the decay of the mechanical properties of reinforcements modify the collapse mode of the section. In cases of corrosion losses up to $5 \%$ in mass loss, the sectional collapse is governed by the reinforcement and not by the concrete anymore. Then, when the pitting corrosion damages the formed beam, the residual flexural strength of the elements strongly depends on the amount of longitudinal reinforcements. In a different way, in the case of the flat beam, corrosion modifies the collapse mode only for higher mass losses, and the dependence of the flexural decay law on the longitudinal reinforcements amount appears quite negligible.
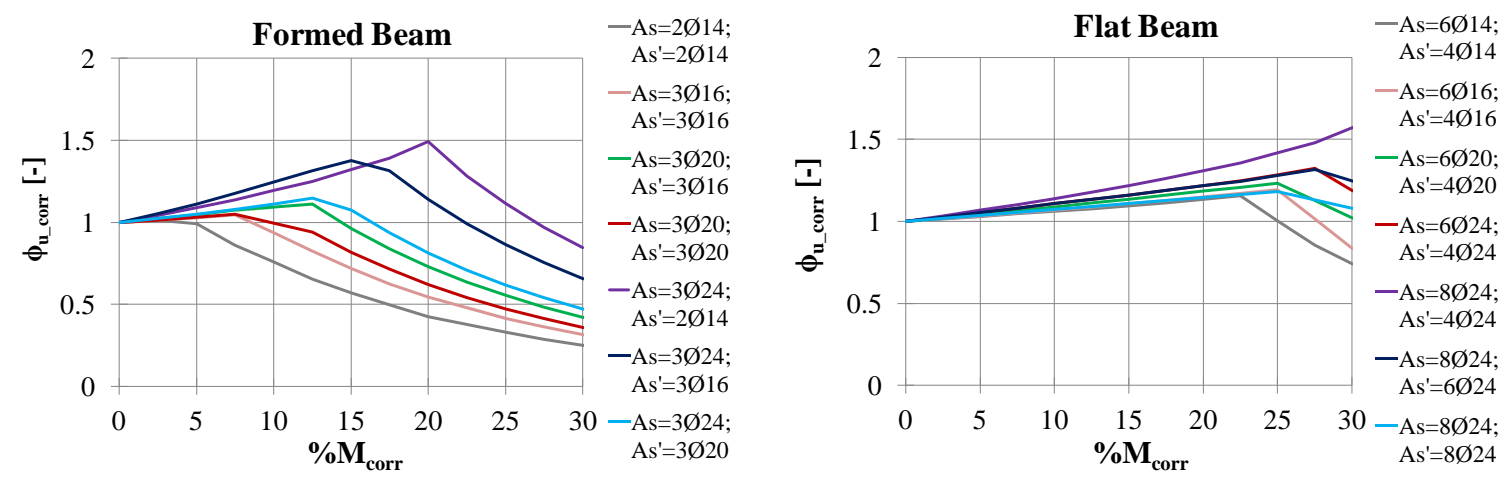

Figure 10. Nondimensional ultimate curvature after the pitting corrosion: differences between the flat and the formed beams.

The abaci previously reported were defined considering beams whose dimensions and reinforcement comply with the principles of the current codes; the geometrical reinforcement percentage, in fact, is between $0.18 \%$ and $0.80 \%$ for the formed beams and between $1.75 \%$ and $2.35 \%$ for the flat 
beams. However, code limitations may not be satisfied by existing structures. For instance, in Italy, during the 1970s, the usual employed concrete had a mean (cubic) compressive strength of $20 \mathrm{MPa}$, while the reinforcements belonged to steels that were so-called A38 $\left(\sigma_{y}=380 \mathrm{MPa} ; \sigma_{u}=460 \mathrm{MPa}\right.$; $\left.\varepsilon_{u}=14 \%\right)$ or AQ42 $\left(\sigma_{y}=230 \mathrm{MPa} ; \sigma_{u}=420 \mathrm{MPa} ; \varepsilon_{u}=20 \%\right)$. A $(30 \times 50) \mathrm{cm}^{2}$ cross-section with a concrete cover of thickness equal to $2 \mathrm{~cm}$ typically characterized the formed beams. Moreover, the beams were designed to sustain only the gravitational loads and according to simplified formulations belonging to band criteria. Specifically, in compression, only two $12 \mathrm{~mm}$ diameter rebars were applied, with the mere function to support the stirrups, while in tension, from 2 to 6 bars with a diameter in the range from $12 \mathrm{~mm}$ to $22 \mathrm{~mm}$ were provided, depending on the effective load level. Some examples of abaci obtained for this typical condition are reported in Figure 11. The obtained results demonstrate once again the dangerousness of the pitting corrosion and the quasi-parabolic shape of the decay laws that are strictly related to the initial reinforcements mechanical properties.
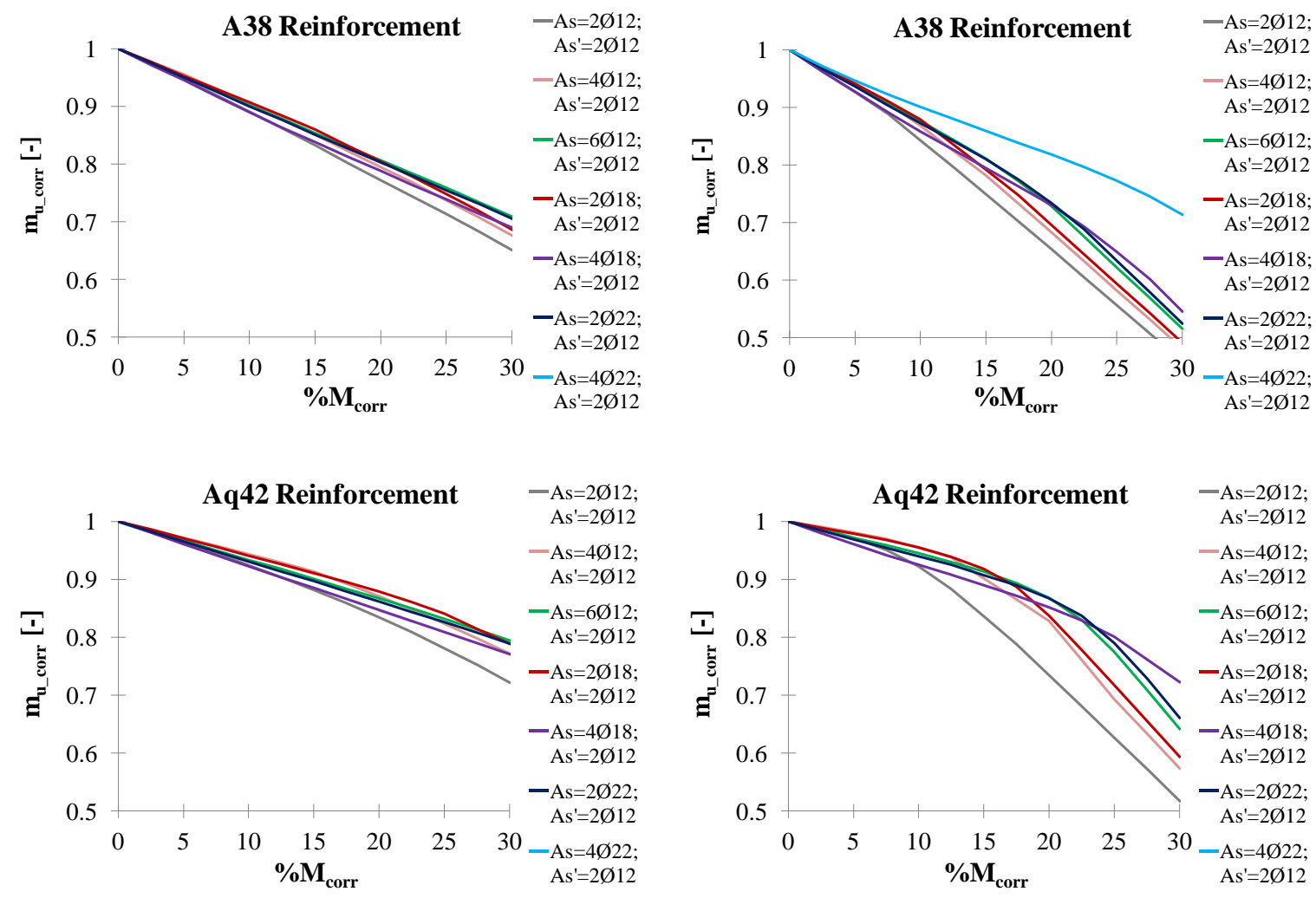

Figure 11. Nondimensional ultimate bending moment for existing formed beams: on the left the case of the uniform corrosion, on the right the pitting corrosion.

\section{Conclusions}

Corrosion degradation can occur on reinforced concrete structures, causing loss of load-bearing capacity both in the service and in the ultimate limit state. To estimate the residual life of a reinforced concrete structure subjected to corrosion, a reliable procedure does not yet exist, even if it is now well known that the first aspects to consider are related to reinforcement degradation, and concrete cracking and cover spalling and decay in the between concrete and steel and.

In order to predict the mechanical behavior of a corroded RC beam, an experimental case was selected and analyzed by means of a nonlinear finite element method. The obtained results indicate good agreement with experimental observation at the ultimate and serviceability limit state, proving the accuracy and applicability of the adopted decay laws in the case of the uniform corrosion (Equations (1)-(4)). In the case of the pitting corrosion, instead, the reliability of the approach has already been demonstrated in other, previous studies [47,55]. The application of decay laws for the 
steel to the classical models of the structural engineering allows definition of a useful tool to estimate the residual flexural strength of the corroded RC element (Figures 6-11). The proposed abaci clearly highlight once again the dangerousness of corrosion degradation.

Author Contributions: Data curation, S.I. and M.K.; Investigation, S.I. and M.K.; Methodology, S.I. and A.B.; Supervision, A.B.; Validation, M.K.; Writing—original draft, S.I., M.K., and A.B.; Writing-review and editing, A.B., M.K., and S.I.

Funding: This research received no external funding.

Acknowledgments: This paper is part of the research convention "Effect of the corrosion on the steel-to-concrete interaction" between Niccolò Cusano University and Oslo Metropolitan University. We would like to show our gratitude to the Oslo Metropolitan University for the financial support of this project.

Conflicts of Interest: The authors declare no conflict of interest.

\section{References}

1. Bossio, A.; Monetta, T.; Bellucci, F.; Lignola, G.P.; Prota, A. Modeling of concrete cracking due to corrosion process of reinforcement bars. Cem. Concr. Res. 2015, 71, 78-92. [CrossRef]

2. Markeset, G.; Kioumarsi, M. Need for further development in service life modelling of concrete structures in chloride environment. Proc. Eng. 2017, 171, 549-556. [CrossRef]

3. Almusallam, A.A. Effect of degree of corrosion on the properties of reinforcing steel bars. Constr. Build. Mater. 2001, 15, 361-368. [CrossRef]

4. Cairns, J.; Plizzari, G.A.; Du, Y.; Law, D.W.; Franzoni, C. Mechanical properties of corrosion-damaged reinforcement. ACI Mater. J. 2005, 102, 256.

5. Apostolopoulos, C.A.; Papadopoulos, M.P. Tensile and low cycle fatigue behavior of corroded reinforcing steel bars S400. Constr. Build. Mater. 2007, 21, 855-864. [CrossRef]

6. Lee, H.S.; Cho, Y.S. Evaluation of the mechanical properties of steel reinforcement embedded in concrete specimen as a function of the degree of reinforcement corrosion. Int. J. Fract. 2009, 157, 81-88. [CrossRef]

7. Apostolopoulos, C.A.; Demis, S.; Papadakis, V.G. Chloride-induced corrosion of steel reinforcementMechanical performance and pit depth analysis. Constr. Build. Mater. 2013, 38, 139-146. [CrossRef]

8. Kashani, M.M.; Crewe, A.J.; Alexander, N.A. Nonlinear stress-strain behaviour of corrosion-damaged reinforcing bars including inelastic buckling. Eng. Struct. 2013, 48, 417-429. [CrossRef]

9. Kashani, M.M.; Crewe, A.J.; Alexander, N.A. Nonlinear cyclic response of corrosion-damaged reinforcing bars with the effect of buckling. Constr. Build. Mater. 2013, 41, 388-400. [CrossRef]

10. Caprili, S.; Salvatore, W. Cyclic behaviour of uncorroded and corroded steel reinforcing bars. Constr. Build. Mater. 2015, 76, 168-186. [CrossRef]

11. Imperatore, S.; Rinaldi, Z.; Drago, C. Degradation relationships for the mechanical properties of corroded steel rebars. Constr. Build. Mater. 2017, 148, 219-230. [CrossRef]

12. Al-Sulaimani, G.J.; Kaleemullah, M.; Basunbul, I.A. Influence of corrosion and cracking on bond behavior and strength of reinforced concrete members. ACI Struct. J. 1990, 87, 220-231.

13. Andrade, C.; Alonso, C.; Molina, F.J. Cover cracking as a function of bar corrosion: Part I-Experimental test. Mater. Struct. 1993, 26, 453-464. [CrossRef]

14. Cabrera, J.G. Deterioration of concrete due to reinforcement steel corrosion. Cem. Concr. Compos. 1996, 18, 47-59. [CrossRef]

15. Broomfield, J.P. Corrosion of Steel in Concrete: Understanding, Investigation and Repair; CRC Press: London, UK, 2003.

16. Vidal, T.; Castel, A.; Francois, R. Corrosion process and structural performance of a 17 year old reinforced concrete beam stored in chloride environment. Cem. Concr. Res. 2007, 37, 1551-1561. [CrossRef]

17. Bossio, A.; Lignola, G.P.; Fabbrocino, F.; Monetta, T.; Prota, A.; Bellucci, F.; Manfredi, G. Nondestructive assessment of corrosion of reinforcing bars through surface concrete cracks. Struct. Concr. 2017, 18, 104-117. [CrossRef]

18. Almusallam, A.A.; Al-Gahtani, A.S.; Aziz, A.R. Effect of reinforcement corrosion on bond strength. Constr. Build. Mater. 1996, 10, 123-129. [CrossRef] 
19. Lee, H.S.; Noguchi, T.; Tomosawa, F. Evaluation of the bond properties between concrete and reinforcement as a function of the degree of reinforcement corrosion. Cem. Concr. Res. 2002, 32, 1313-1318. [CrossRef]

20. Coronelli, D. Corrosion cracking and bond strength modeling for corroded bars in reinforced concrete. ACI Struct. J. 2002, 99, 267-276.

21. Fang, C.; Lundgren, K.; Plos, M.; Gylltoft, K. Bond behaviour of corroded reinforcing steel bars in concrete. Cem. Concr. Res. 2006, 36, 1931-1938. [CrossRef]

22. Chung, L.; Kim JH, J.; Yi, S.T. Bond strength prediction for reinforced concrete members with highly corroded reinforcing bars. Cem. Concr. Compos. 2008, 30, 603-611. [CrossRef]

23. Lundgren, K.; Kettil, P.; Hanjari, K.Z.; Schlune, H.; Roman AS, S. Analytical model for the bond-slip behaviour of corroded ribbed reinforcement. Struct. Infrastruct. Eng. 2012, 8, 157-169. [CrossRef]

24. Choi, Y.S.; Yi, S.T.; Kim, M.Y.; Jung, W.Y.; Yang, E.I. Effect of corrosion method of the reinforcing bar on bond characteristics in reinforced concrete specimens. Constr. Build. Mater. 2014, 54, 180-189. [CrossRef]

25. Coccia, S.; Imperatore, S.; Rinaldi, Z. Influence of corrosion on the bond strength of steel rebars in concrete. Mater. Struct. 2016, 49, 537-551. [CrossRef]

26. Rodriguez, J.; Ortega, L.M.; Casal, J. Corrosion of reinforcing bars and service life of reinforced concrete structures: Corrosion and bond deterioration. In Proceedings of the International conference on concrete across borders, Odense, Denmark, 22-25 June 1994; Volume 2, pp. 315-326.

27. Rodriguez, J.; Ortega, L.M.; Casal, J. Load carrying capacity of concrete structures with corroded reinforcement. In Proceedings of the International Conference on Structural Faults Repairs, London, UK, July 1995; Volume 2, pp. 189-198.

28. Rodriguez, J.; Ortega, L.M.; Casal, J.; Diez, J.M. Corrosion of reinforcement and service life of concrete structures. In Proceedings of the 7th International Conference on Durability of Building Materials and Components, Stockholm, Sweden, 19-23 May 1996.

29. Rodriguez, J.; Ortega, L.M.; Casal, J.; Diez, J.M. Assessing structural conditions of concrete structures with corroded reinforcement. In Concrete Repair, Rehabilitation and Protection; Dhir, R.K., Jones, M.R., Eds.; EFN Spon: London, UK, 1996; pp. 65-78.

30. Rodriguez, J.; Ortega, L.M.; Casal, J. Load carrying capacity of concrete structures with corroded reinforcement. Constr. Build. Mater. 1997, 11, 239-248. [CrossRef]

31. Capozucca, R.; Cerri, M.; Mariotti, A.; Menditto, G. Behaviour of rc structures subject to reinforcement corrosion. In Proceedings of the 5th International Conference on Structural Faults and Repairs, Edinburgh, UK, 29 June 1993.

32. Mangat, P.S.; Elgarf, M.S. Flexural strength of concrete beams with corroding reinforcement. ACI Struct. J. 1999, 96, 149-158.

33. Castel, A.; François, R.; Arliguie, G. Mechanical behaviour of corroded reinforced concrete beams-Part 1: Experimental study of corroded beams. Mater. Struct. 2000, 33, 539-544. [CrossRef]

34. Torres-Acosta, A.A.; Navarro-Gutierrez, S.; Terán-Guillén, J. Residual flexure capacity of corroded reinforced concrete beams. Eng. Struct. 2007, 29, 1145-1152. [CrossRef]

35. Azad, A.K.; Ahmad, S.; Azher, S.A. Residual strength of corrosion-damaged reinforced concrete beams. ACI Mater. J. 2007, 104, 40.

36. Zhang, R.; Castel, A.; François, R. Serviceability limit state criteria based on steel-concrete bond loss for corroded reinforced concrete in chloride environment. Mater. Struct. 2009, 42, 1407. [CrossRef]

37. Du, Y.; Cullen, M.; Li, C. Structural performance of RC beams under simultaneous loading and reinforcement corrosion. Constr. Build. Mater. 2013, 38, 472-481. [CrossRef]

38. Xia, J.; Jin, W.L.; Li, L.Y. Effect of chloride-induced reinforcing steel corrosion on the flexural strength of reinforced concrete beams. Magaz. Concr. Res. 2012, 64, 471-485. [CrossRef]

39. Zhu, W.; François, R.; Coronelli, D.; Cleland, D. Effect of corrosion of reinforcement on the mechanical behaviour of highly corroded RC beams. Eng. Struct. 2013, 56, 544-554. [CrossRef]

40. Zhu, W.; François, R. Corrosion of the reinforcement and its influence on the residual structural performance of a 26-year-old corroded RC beam. Constr. Build. Mater. 2014, 51, 461-472. [CrossRef]

41. Vu KA, T.; Stewart, M.G. Structural reliability of concrete bridges including improved chloride-induced corrosion models. Struct. Saf. 2000, 22, 313-333.

42. Coronelli, D.; Gambarova, P. Structural assessment of corroded reinforced concrete beams: Modeling guidelines. J. Struct. Eng. 2004, 130, 1214-1224. [CrossRef] 
43. El Maaddawy, T.; Soudki, K.; Topper, T. Analytical model to predict nonlinear flexural behavior of corroded reinforced concrete beams. ACI Struct. J. 2005, 102, 550.

44. Val, D.V. Deterioration of strength of RC beams due to corrosion and its influence on beam reliability. J. Struct. Eng. 2007, 133, 1297-1306. [CrossRef]

45. Kioumarsi, M.M.; Hendriks, M.A.; Kohler, J.; Geiker, M.R. The effect of interference of corrosion pits on the failure probability of a reinforced concrete beam. Eng. Struct. 2016, 114, 113-121. [CrossRef]

46. Imperatore, S.; Leonardi, A.; Rinaldi, Z. Mechanical behaviour of corroded rebars in reinforced concrete elements. In Mechanics, Models and Methods in Civil Engineering; Maceri, F., Ed.; Springer: Berlin/Heidelberg, Germany, 2012; pp. 207-220.

47. Imperatore, S.; Leonardi, A.; Rinaldi, Z. Strength decay of RC sections for chloride attack. Int. J. Struct. Integr. 2016, 7, 194-212. [CrossRef]

48. Kioumarsi, M.; Markeset, G.; Hooshmandi, S. Effect of pit distance on failure probability of a corroded RC beam. Proc. Eng. 2017, 171, 526-533. [CrossRef]

49. Imperatore, S.; Zucconi, M.; Ferracuti, B. Pitting corrosion effects on the seismic behaviour of existing RC buildings. In Proceedings of the XVII Convegno ANIDIS L'ingegneria Sismica in Italia 2017; Pisa University Press: Pisa, Italy, 2017; pp. 114-124.

50. Bossio, A.; Fabbrocino, F.; Monetta, T.; Lignola, G.P.; Prota, A.; Manfredi, G.; Bellucci, F. Corrosion effects on seismic capacity of reinforced concrete structures. Corros. Rev. 2019, 37, 45-56. [CrossRef]

51. Apostolopoulos, C.; Drakakaki, A.; Basdeki, M. Seismic assessment of RC column under seismic loads. Int. J. Struct. Integr. 2019, 10, 41-54. [CrossRef]

52. Zucconi, M.; Ferlito, R.; Sorrentino, L. Validation and extension of a statistical usability model for unreinforced masonry buildings with different ground motion intensity measures. Bull. Earthq. Eng. 2019, 1-29. [CrossRef]

53. Romano, F.; Faggella, M.; Gigliotti, R.; Zucconi, M.; Ferracuti, B. Comparative seismic loss analysis of an existing non-ductile RC building based on element fragility functions proposals. Eng. Struct. 2018, 177, 707-723. [CrossRef]

54. Ferlito, R.; Guarascio, M.; Zucconi, M. Assessment of a vulnerability model against post-earthquake damage data: The case study of the historic city centre of L'Aquila in Italy. In Proceedings of the 9th International Conference on Earthquake Resistant Engineering Structures, A Coruña, Spain, 8-10 July 2013.

55. Di Carlo, F.; Meda, A.; Rinaldi, Z. Numerical evaluation of the corrosion influence on the cyclic behaviour of RC columns. Eng. Struct. 2017, 153, 264-278. [CrossRef]

56. DIANA, User's Manual, Release 9.4; TNO DIANA BV: Delft, The Netherlands, 2010.

57. Capozucca, R.; Cerri, M.N. Influence of reinforcement corrosion-In the compressive zone-On the behaviour of RC beams. Eng. Struct. 2003, 25, 1575-1583. [CrossRef]

58. Zandi Hanjari, K.; Kettil, P.; Lundgren, K. Analysis of mechanical behavior of corroded reinforced concrete structures. ACI Struct. J. 2011, 108, 532-541.

59. Kioumarsi, M.M.; Hendriks, M.A.; Geiker, M.R. Quantification of the interference of localised corrosion on adjacent reinforcement bars in a concrete beam in bending. Nord. Concr. Res. 2014, 49, 39-57.

60. Kioumarsi, M.M.; Hendriks, M.A.; Geiker, M.R. Interference of localised corrosion in adjacent reinforcement bar of a beam in bending. In Proceedings of the CIC - Concrete innovation conference, Oslo, Norway, 11-14 June 2014.

61. Fib. Fib Model Code for Concrete Structures 2010; Ernst \& Sohn. Wiley: Berlin, Germany, 2013.

62. European Committee for Standardization. Eurocode 2: Design of Concrete Structures-Part 1-1: General Rules and Rules for Buildings; British Standards Institution: Brussels, Belgium, 2004.

63. Mander, J.B.; Priestley, M.J.; Park, R. Theoretical stress-strain model for confined concrete. J. Struct. Eng. 1988, 114, 1804-1826. [CrossRef]

(C) 2019 by the authors. Licensee MDPI, Basel, Switzerland. This article is an open access article distributed under the terms and conditions of the Creative Commons Attribution (CC BY) license (http://creativecommons.org/licenses/by/4.0/). 